\title{
Measure of E-Cash on Delivery Payment Convenience Option in the Context of Demonetisation and its Effect on Customer Loyalty
}

Sudipta Kumar Jana*

\begin{abstract}
The rapidly changing business environment in India, particularly after demonetization, has made marketers understand the complex behaviour of consumers. Online retailers in India do not want to miss any opportunity to serve customers in a better way and enhance customer convenience. Since the Indian market is very dynamic, it is very important to understand the different factors affecting customer purchase decision; among these different factors, customer payment options are an important factor. Although online retailers offer several modes of payment, demonetization has changed the entire equation. This paper studies the measure of e-COD payment convenience scale, its validity, reliability and how it affects customer loyalty. Research methods like confirmatory factor analysis and structural equation modelling have been applied with the help of SPSS and AMOS.
\end{abstract}

Keywords: E-Cash on Delivery, Confirmatory Factor Analysis and Structural Equation Modelling

* Indian Institute of Production Management, Odisha, India; 770034sudiptajana82@gmail.com 


\section{Introduction}

India is a country with 942.6 million people over the age of 18; 254.5 million people use the internet which is $27 \%$ of the population; 83 million people shop online i.e. $8.7 \%$ of the population; the percentage of e-commerce in the GDP is $1.23 \%$; $33 \%$ of the population uses smartphone and of the total online sales, $20 \%$ arises from mobile phones (Willemsen, Abraham and Welje, 2016). There is a great opportunity for the growth of E-commerce Industry in India, but this Industry is at crossroads. The Indian Government is very much excited about its "Digital India" project. The Government of India is investing heavily in developing the information technology infrastructure in India. The "Digital India" Programme will give a strong boost to e-commerce and ultimately will fuel the growth of cashless transactions in the country. There has been an upsurge in online payments after the event of demonetization in India. In the context of demonetization ecommerce giants like Amazon and Flipkart took no time to stop their cash on delivery options and educated their customers about the benefits of e-cash payments. Although cash on delivery makes $80 \%$ of the sales, in the long run, cashless transactions will not only be beneficial to business houses but to the customers as well. Cashless transactions will not only bring transparency and convenience but will give a boost to the economy.

The Government's decision on November 8, 2016, to ban Rs.500 and Rs.1000, created a flutter in many sections of the society. Indian Newspapers were flooded with news on the cash crisis and the difficulties arising out of it thereby. Most financial transactions came under the scanner of different statutory authorities and the country was gearing towards a cashless society. Indian customers are value conscious and love to bargain, every time they shop. The cash crisis in the context of demonetization has driven people towards digital payment methods, such as mobile wallets, internet banking, debit and credit cards. Most of the business sectors reported a negative growth, but positive news came from organisations like Paytm, Freecharge, Mobikwik, Citrus Pay etc. and these organisations enjoyed a manifold increase in users. 


\section{Literature Review}

Limayem et al. (2000) noted that personal innovativeness has direct and indirect effects on online shopping and the relationship was further mediated by customer attitude. Tsai and Yeh (2000) emphasised on the role of quality of websites in the purchase of environmentally sustainable products. Vrechopoulos (2001) in his study on internet shopping adoption by Greek consumers mentioned that information about products, its alternatives along with price comparisons, quick access to the store's website, are the important drivers for online shopping. Smith and Hantula (2003) in their study on "Pricing effects on foraging in a simulated Internet shopping mall" emphasised that low priced stores offered better varieties and options of merchandise as well as better service. Teo and Leong (2004) in their study on customers from USA and China, revealed that transaction cost has a negative impact on the willingness of customers to pay online. Harn et al. (2006) in their study on Malaysian customers, mentioned that "privacy and trust" are the important factors in online shopping. Over by and Lee (2006) in their study revealed that utilitarian value was more important than the hedonic value in predicting the future buying intentions of customers towards online buying. Gupta and Kim (2007) in their study revealed that customers' perceived price and convenience has an impact on customers repurchase intentions. Lo and Harvey (2011) emphasised that credit card allows compulsive buyers to overspend and they were rarely influenced by price. Liao et al. (2012) in their study found that online buying is a win - win situation for both buyers as well as sellers. They further mentioned that knowledge extraction from data mining can be useful for group buying firms. Guo et al. (2012) in their study on online shopping in China highlighted the importance of "Payment method" along with other factors in driving customer satisfaction. Jiang et al. (2012) in their study on "measuring consumer perceptions of online shopping convenience" revealed five important dimensions, namely, access, search, evaluation, transaction and possession that drive customers towards an online purchase. Guo et al. (2012) in their study outlined the importance of website design, security, information quality, payment method etc. has a positive influence on customer satisfaction. Silpa et al. (2016) 
in their study on people's perception towards online shopping concluded that online shopping was much convenient and the demand for online shopping would be much more in the near future. Lian and Yeu (2014) concluded that there is an increasing tendency of older adults towards online shopping. Padmaja and Mohan (2015) in their study on online buying behaviour observed that convenience, discounts and variety options are the important drivers of online purchase. Kumudha and Lakshmi (2016) in their study post demonetization revealed that online shopping and digital payment method are highly correlated.

\section{Objectives of the Study}

For the purpose of the present study, Flipkart customers are chosen because of the popularity of the e-retailer. From the review of the literature, the present paper aims to study the validity and reliability of "e-cash on delivery" measure, its application in the context of e-tailing and its effect on consumer loyalty.

Hypothesis H1: e-Cash on delivery option provided by Flipkart has a significant effect on brand loyalty.

\section{Methodology}

The present study was conducted in Rourkela city of Odisha in India and for the purpose of the present study, convenient sampling was used. Data was collected from Flipkart customers with the help of structured questionnaire. Although 650questionnaires were distributed and 527 filled in questionnaire were received, only 509 were used and the rest were discarded because they were either incompletely filled or were biased. To measure e-cash on delivery convenience a new measure was developed by selecting and modifying items from previous measures (Guo et al. 2012; Jiang et al. 2013). However, to measure customer loyalty Oliver (1999) measure was adopted for the study. Confirmatory factor analysis and structural equation modellinghave been applied in measurement model and structural model respectively. 
Sudipta Kumar Jana Demonetisation and its Effect on Customer Loyalty

\section{Data Analysis and Results}

Most of the respondents in the present study were private sector employees while students and housewives formed the rest of the respondents. The marital status of most of the respondents was unmarried. A two-step approach i.e. measurement model(Figure-1) followed by structural model, was adopted for the study, as suggested by Anderson\& Gerbing (1988). A measurement model visualises empirically, how the different items or variables truly represents a construct. The confirmatory factor analysis provided acceptable model fit indices (Table 1) as suggested by $\mathrm{Hu}$ and Bentler (1999), (Chi-square $=55.606$, df $=34 ; \mathrm{p}<0.000)$, Normed fit index $(\mathrm{NFI})=.860$; Comparative fit index $(\mathrm{CFI})=.939$; and Root mean square error of approximation (RMSEA) $=.035$ as suggested by Nunnally \& Bernstein (1994).

Table 1: Fit Indices for Measurement Model (N=509)

\begin{tabular}{lccccccccc}
\hline $\begin{array}{l}\text { Fit } \\
\text { Indices }\end{array}$ & $X^{2}$ & df & GFI & AGFI & RMSEA & NFI & CFI & PNFI & PCFI \\
Values & 55.606 & 34 & .978 & .965 & 0.03 & .860 & .939 & .650 & .709 \\
\hline
\end{tabular}

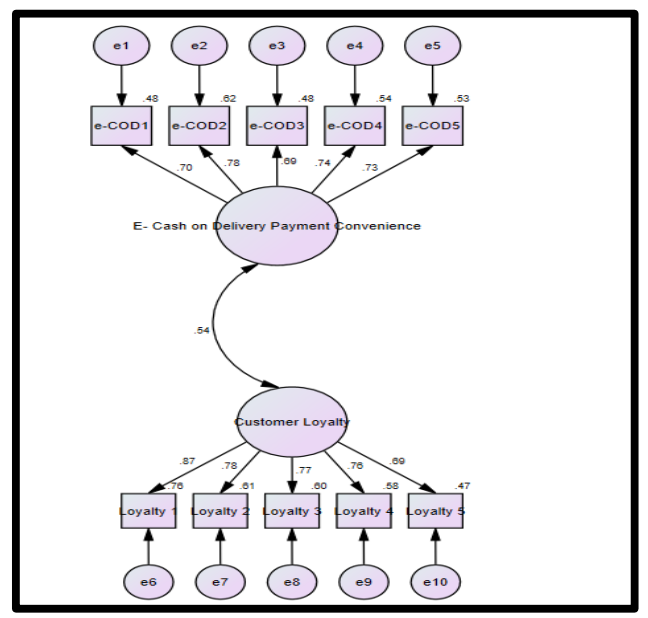

Fig1 Measurement Model

To test the convergent validity, average variance extracted was calculated (Table: 2) and for all the factors, where the unit of variance was fixed to 1 as suggested by Bryne (2001), values were 
above the cut of value of 0.5 as mentioned by Kline (1998) and Fornell and Larcker (1981). All the constructs displayed appropriate reliability results because the construct reliability values (Table: 2 ) of all the measures were above the cut off value of 0.7 , as suggested by (Malhotra, 1981).

Table 2: Construct Reliability and Average Variance Extracted (AVE) for Latent Variables (N=509)

\begin{tabular}{lcc}
\hline & $\begin{array}{c}\text { e-Cash on Delivery } \\
\text { Payment Convenience }\end{array}$ & Customer Loyalty \\
$\begin{array}{l}\text { Reliability Statistics } \\
\text { (Cronbach's Alpha) }\end{array}$ & 0.084 & .879 \\
$\begin{array}{l}\text { Average Variance } \\
\text { Extracted (AVE) }\end{array}$ & 0.53 & 0.63 \\
\hline
\end{tabular}

Similarly, to test the divergent validity, the squared correlation values among the constructs were compared with the average variance values and was found that (see Table:3) the squared correlation values were less than the Average variance extracted. So from the above results, the researchers conclude that all the constructs used in the study displayed appropriate convergent and divergent validity and reliability as well.

Table 3: Standardized Correlations (Squared Correlation) for Latent Variables ( $\mathrm{N}=509)$

\begin{tabular}{lcc}
\hline & $\begin{array}{c}\text { e-Cash on Delivery } \\
\text { Payment Convenience }\end{array}$ & $\begin{array}{c}\text { Customer } \\
\text { Loyalty } \\
\text { e-Cash on Delivery }\end{array}$ \\
$\begin{array}{l}\text { Payment Convenience } \\
\text { Customer Loyalty }\end{array}$ & 1 & $.54(0.29)$ \\
\hline
\end{tabular}

A structural theory is a conceptual representation of the structural relationships between constructs. In the present study, the structural relationship proposed direct relationship from e-cash on delivery convenience on customer loyalty. From the structural model it was found that standardized parameter estimates for the relationship of e-cash on delivery payment convenience to customer loyalty $=.54$. So we conclude that the formulated hypothesis is supported. 


\section{Conclusions and Recommendations}

Empirically it is proved that, e-cash on delivery payment measure is valid as well as reliable in the context of e-tailing. Taking advantage of the "Jan Dhan Yojna", initiated by the Government of India, which has added, over 110 million debit card users, e-tailers must adapt to e-cash on delivery. The launch of Unified Payment Interface (UPI) by the Reserve Bank of India will further ease the process of online payments. Although India is a cash based society and as of now cash on delivery is the best payment method preferred by customers, e-tailers can still adapt and convince customers for e-cash on delivery. Customers need to be made aware of the benefits of e-cash payments in overcoming problems like, fraud by cash collection agent, high financial cost in the form of labour, risky cash handling etc. The major limitations of the present study were that data was collected from only Flipkart customers in Rourkela city of Odisha. This study can be replicated in some other segments. Further research could be conducted to find the effect of e-cash on delivery on consumer trust in the context of new e-tailers.

\section{References}

Anderson, J. C., \& Gerbing, D. W. (1988). Structural equation modeling in practice: A review and recommended two-step approach. Psychological bulletin, 103(3),411-423

Byrne, B. (2001). Structural Equation Modeling with AMOS, EQS, and LISREL: Comparative Approaches to Testing for the Factorial Validity of a Measuring Instrument. International Journal of Testing,1(1), 55-86.

Eroglu, S. A., Machleit, K. A., \& Davis, L. M. (2001). Atmospheric qualities of online retailing: A conceptual model and implications. Journal of Business research, 54(2), 177-184.

Fornell, C., \& Larcker, D.F. (1981). Evaluating structural equation models with unobservable variables and measurement error. Journal of Marketing Research, 18(1), 39-50.

Guo, X., Ling, K. C., \& Liu, M. (2012). Evaluating factors influencing consumer satisfaction towards online shopping in China. Asian Social Science, 8(13), 40-50.

Gupta, S., \& Kim, H. W. (2007). The moderating effect of transaction experience on the decision calculus in on-line repurchase. International Journal of Electronic Commerce, 12(1), 127-158. 
Harn, A. C. P., Khatibi, A., \& Ismail, H. (2006). E-Commerce: A study on online shopping in Malaysia. Journal of Social Sciences, 15(5), 232-242.

$\mathrm{Hu}, \mathrm{L}$. \& Bentler, P. (1999). Cutoff criteria for fit indexes in covariance structure analysis: Conventional criteria versus new alternatives. Structural Equation Modeling: A Multidisciplinary Journal, 6(1), 1-55.

Jiang, L., Yang, Z., \& Jun, M. (2013). Measuring consumer perceptions of online shopping convenience. Journal of Service Management, 24(2), 191214.

Kumudha, A. \& Lakshmi, K. (2016). Digital Marketing: Will the Trend Increase in the Post Demonetization Period. Quest Journals Journal of Research in Business and Management, 4(10), 94-97.

Lian, J. W., \& Yen, D. C. (2014). Online shopping drivers and barriers for older adults: Age and gender differences. Computers in Human Behavior, 37, 133-143.

Liao, S. H., Chu, P. H., Chen, Y. J., \& Chang, C. C. (2012). Mining customer knowledge for exploring online group buying behavior. Expert Systems with Applications, 39(3), 3708-3716.

Limayem, M., Khalifa, M., \& Frini, A. (2000). What makes consumers buy from Internet? A longitudinal study of online shopping. IEEE Transactions on Systems, Man, and Cybernetics-Part A: Systems and Humans, 30(4), 421-432.

Lo, H. Y., \& Harvey, N. (2011). Shopping without pain: Compulsive buying and the effects of credit card availability in Europe and the Far East. Journal of Economic Psychology, 32(1), 79-92.

Malhotra, N. K. (1981). A scale to measure self-concepts, person concepts, and product concepts. Journal of marketing research, 4(18), 456-464.

Nunally, J. \& Bernstein, I. H. (1994). Psychometric Theory, New York, McGrawHill.

Oliver, R. (1999). Whence Consumer Loyalty? Journal of Marketing, 63 (Special Issue): 33-44.

Overby, J. W., \& Lee, E. J. (2006). The effects of utilitarian and hedonic online shopping value on consumer preference and intentions. Journal of Business research, 59(10), 1160-1166.

Padmaja, P. \& Mohan, D. (2015). Determinants of Consumer On-Line Buying Behavior - A Study to measure the impact of consumer demographics in online buying in Bengaluru City, India. IOSR Journal of Business and Management, 17(8), 79-86.

Silpa, K., Rajasree, P., \& Balasubramanian, D. (2016). A Study on Peoples' Perceptions towards Online Shopping. Bonfring International Journal of Industrial Engineering and Management Science, 6(3), 93-95. 
Sudipta Kumar Jana Demonetisation and its Effect on Customer Loyalty

Smith, C. L., \& Hantula, D. A. (2003). Pricing effects on foraging in a simulated Internet shopping mall. Journal of Economic Psychology, 24(5), 653-674.

Teo, T. S., Wang, P., \& Leong, C. H. (2004). Understanding online shopping behaviour using a transaction cost economics approach. International Journal of Internet Marketing and Advertising, 1(1), 62-84.

Tsai, Y. C., \& Yeh, J. C. (2010). Perceived risk of information security and privacy in online shopping: A study of environmentally sustainable products. African Journal of Business Management, 4(18), 40-57.

Vrechopoulos, A. P., Siomkos, G. J., \& Doukidis, G. I. (2001). Internet shopping adoption by Greek consumers. European Journal of Innovation Management, 4(3), 142-153.

Willemson, R., Abraham, J., \& Welje, R. V. (2016). India B2C E-Commerce Report 2016 (Rep.). Amsterdam: Ecommerce Foundation. 